UDC 504.4

DOI https://doi.org/10.32838/2663-5941/2020.2-2/08

Tkachuk K.K.

National Technical University of Ukraine "Igor Sikorsky Kyiv Polytechnic Institute"

Tverda O.Ya.

National Technical University of Ukraine "Igor Sikorsky Kyiv Polytechnic Institute"

Repin M.V.

National Technical University of Ukraine "Igor Sikorsky Kyiv Polytechnic Institute"

\title{
EFFECTIVENESS OF IMPLEMENTATION OF THE INSTALLATION FOR NATURAL RESERVOIR CLEANING
}

Article is devoted to main problems of hazardous situation in rivers reservoirs are: discharges of under treated industrial sewage, household sewage water, increase of organic matter amounts, lowering the water level of reservoir during warm season, active uncontrolled growth of blue-green algae. In order to designate the measures for improving the quality of water in reservoirs, here is proposed the method of "choosing the best alternative". This method allows execution of a comparative analysis of alternative measures using enumeration which includes technological parameters and organizational measures, provided with norms. In this thesis there is proposed a method justification for the measures to improve water quality. The solution of multi-criteria task via the method of choosing the best alternatives without full information allows numerical estimation of the water quality lowering possibility and to choose the best available method of increasing water quality in reservoirs. To choose and justify the measures that will ensure increasing of water quality in natural water reservoirs, there was carried out comparative analysis to determine the viability of alternative suggestions using a list of parameters and measures to search the best alternatives. Economic effectiveness of modelled measures is calculated with the indicator of the overall economic efficiency of environmental protection expenses. The effectiveness of the expenses is determined basing on the environmental protection substantiation stages and in process of results estimation for environmental protection program tasks and regional usage of natural resources on certain territory. The determination of environmental protection measures' pure ecological effect bases on comparing the expenses for their implementation to achieved result through these measures.

Key words: sewage water, water quality, comprehensive, analytical indicators, natural resources.

Introduction. The main problems of hazardous situation in Dnipro reservoirs are: discharges of under treated industrial sewage, household sewage water, increase of organic matter amounts, lowering the water level of reservoir during warm season, active uncontrolled growth of blue-green algae. In order to designate the measures for improving the quality of water in reservoirs, here is proposed the method of "choosing the best alternative" [1]. This method allows execution of a comparative analysis of alternative measures using enumeration which includes technological parameters and organizational measures, provided with norms.

Purpose of the article. Improving the efficiency of activities for natural reservoir cleaning.

Statement of the main research material. The solution of multi-criteria task via the method of choosing the best alternative in the condition of information lack allows numerical estimation for the probability of enormous uncontrolled algal growth appear- ance. Because of one or another reason and according to that, recommend the best available measures or means to increase the water quality.

In this thesis there is proposed a method justification for the measures to improve water quality. This method allows identification of the process or parameter that can cause hazardous situation in water reservoir. The minus of this method is there is need to determine weighing factor for every specific point. On the other side this helps to estimate more precisely the reasons of possible hazards' appearance of lowering the water quality occurrence, and accordingly fitting measures to solve the problem.

The solution of multi-criteria task via the method of choosing the best alternatives without full information allows numerical estimation of the water quality lowering possibility and to choose the best available method of increasing water quality in reservoirs.

The criteria for the task solution on finding the most likely reason of water quality deterioration are: 
degree of sewage treatment, rates of blue-green algae growth, amount of organic matter in water of the reservoir, rates of reservoir's ability to self-purification, and changes of water levels.

Economic effectiveness of modelled measures is calculated with the indicator of the overall economic efficiency of environmental protection expenses. This indicator is used when justified structure and volumes of environmental protection measures (including construction of environmental protection objects) and amount of capital investments of environmental protection purposes.

The main value of this indicator and also pure economic effect of environmental protection measures have for substantiation of project decision and for object of given type and capacity.

The effectiveness of the expenses is determined basing on the environmental protection substantiation stages and in process of results estimation for environmental protection program tasks and regional usage of natural resources on certain territory. There are three approaches to determining the economic effectiveness of environmental expenses:

- basing on expenses minimization of determined expenses;

- by comparison of the expenses with normal state of environment;

- by comparison of the expenses with the valuation of distorted economic losses (calculation of total economic efficiency).

The first approach has somewhat limited representation on real ecologic and economic effect as it is used for comparison of different variations of environmental protection activities and samples of environmental protection technologies, and estimates technical-ecological efficiency itself.

The second approach uses system of natural indicators which characterize "normal state of environment". This means that effectiveness is calculated basing on expenses needed for achieving desirable (determined by norms) state of environment.

Due to lack of ecological standards' scientific development and to high practical cost of their achievement this approach hasn't got widening, though it is the most suitable for environmental protection activities aims from ecological point of view.

The most widespread approach is the one that allows fully enough take into account social and economic consequences of contamination by the way of comparison the expenses for environmental protection measures and its results, it allows to study deeper the expenses and losses and in such way estimate the economic effectiveness of environmental protection activity. This approach enables taking into account the expenses for reimbursement of ecological harm as inevitable production expenses.

Pure economic effect of environmental protection measures is determined aiming the justification of technical and economic choice of the best alternatives which differ among themselves by influence on environment and by influence of production results of the industries and subject of economic activity. The determination of environmental protection measures' pure ecological effect bases on comparing the expenses for their implementation to achieved result through these measures.

But because of the situation, where for calculation of ecological and economic effect there is a need in operating installation which is impossible at this stage of investigations. This is why considered above approaches are unavailable. But there is a way to calculate the ecological and economic effect of the developed model of the installation. The formula of economic effect should be used. The empirical formula of economic effect looks as follows:

$$
E=a_{1}^{*} x_{1}+a_{2}^{*} x_{2}+\ldots+a_{i}^{*} x_{i}+a_{n}^{*} x_{n}
$$

with: $a_{i}$ - average cost of yearly deposit (of the implemented measure) in $i$ direction of measure completion, i.e. the average increase of pure income per year provided by this measure (using method of expert evaluation); $\mathrm{x}_{\mathrm{i}}$ - amount of possible measures for $i$ direction.

The realization of these measures can give increase of economic effect:

- minimum (pessimistic scenario) per 10\%;

- maximum (optimistic scenario) per 17\%.

As an income taken is effectiveness of the installation in cleaning the water, which means the level for which water was purified after implementation of the installation. In case of pessimistic scenario water will be cleaner per $10 \%$ (Table 1). And in case of optimistic scenario water will be cleaner per $17 \%$ (Table 1 ). All the calculations are based on existing data and on the results of previous calculations, analyses, and investigations [2].

On the table we can observe calculated results of installation operations. Basing on it we can theoretically estimate operation of the installation.

Before getting any income, there is a need of constructing the installation from the existing parts. For construction of the "Swan" we need 2 filters SmartPondFilter EBF-1200G $\left(900 \mathrm{~m}^{3}\right)$, one diesel engine Centaur 4L22BT (35 HP), container, and hull (Table 2). Their prices are listed in the Table 2. All the spending 
is substituted basing on average prices for the parts that are variable.

From the Table 2 we can see that the cost of hull is approximate because the hull for the "Swan" is unique and there is no price for such constructions in ship building companies. Also, the cost of the instal- lation construction can vary because depending on type of filters, engine and container (its price is added to the price of the hull) [3].

All the constituents chosen are the best alternatives between the offered on the market by few parameters: volume (amount of water let through the filter

\section{Change of water quality indexes for pessimistic scenario and for optimistic scenario}

Table 1 at peak of algae bloom

\begin{tabular}{|c|c|c|c|c|c|c|c|c|c|c|c|}
\hline \multirow[b]{2}{*}{ Place } & \multirow[b]{2}{*}{$\begin{array}{l}0 \\
0 \\
0 \\
0 \\
0 \\
0 \\
0 \\
0 \\
0 \\
0\end{array}$} & \multirow[b]{2}{*}{ 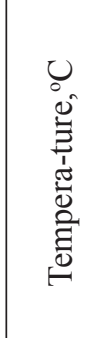 } & \multicolumn{3}{|c|}{$\begin{array}{c}\text { Factual main indexes of } \\
\text { water quality }\end{array}$} & \multicolumn{3}{|c|}{$\begin{array}{c}\text { Values of main water } \\
\text { quality indexes at } 10 \%\end{array}$} & \multicolumn{3}{|c|}{$\begin{array}{c}\text { Values of main water } \\
\text { quality indexes at } 17 \%\end{array}$} \\
\hline & & & 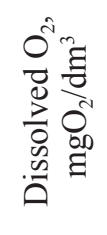 & 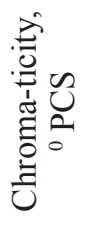 & 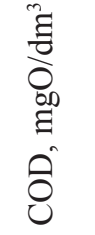 & 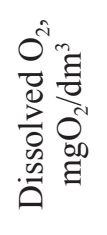 & 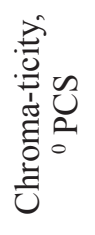 & 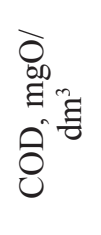 & 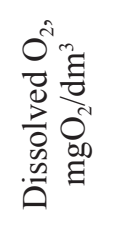 & 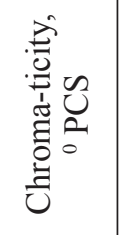 & 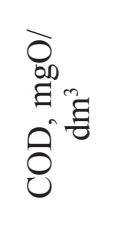 \\
\hline \multirow{2}{*}{ Norm } & \multicolumn{2}{|c|}{ SRN №4630-88 (till 2017) } & $\geq 4,0$ & - & 15 & $\geq 4,0$ & - & 15 & $\geq 4,0$ & - & 15 \\
\hline & \multicolumn{2}{|c|}{ ESWO from 2012} & - & - & 50 & - & - & 50 & - & - & 50 \\
\hline \multirow{2}{*}{ River Ros } & $\begin{array}{l}11.07 . \\
2017\end{array}$ & 23 & 7,7 & 12,6 & 25,2 & 8,47 & 11,34 & 22,68 & 9,009 & 10,458 & 20,916 \\
\hline & $\begin{array}{c}21.08 . \\
2017\end{array}$ & 27 & 5,6 & 18,5 & 36,4 & 6,16 & 16,65 & 32,76 & 6,552 & 15,355 & 30,212 \\
\hline \multirow{2}{*}{ River Ros } & $\begin{array}{l}11.07 . \\
2017 \\
\end{array}$ & 23,2 & 7,1 & 14,7 & 24,8 & 7,81 & 13,23 & 22,32 & 8,307 & 12,201 & 20,584 \\
\hline & $\begin{array}{l}21.08 . \\
2017 \\
\end{array}$ & 27 & 5,4 & 17,2 & 40,5 & 5,94 & 15,48 & 36,45 & 6,318 & 14,276 & 33,615 \\
\hline \multirow{2}{*}{ River Ros } & $\begin{array}{l}10.07 \\
2017 \\
\end{array}$ & 24 & 5,4 & 32 & 39 & 5,94 & 28,8 & 35,1 & 6,318 & 26,56 & 32,37 \\
\hline & $\begin{array}{l}16.08 . \\
2017\end{array}$ & 24,5 & 3,9 & 39 & 41 & 4,29 & 35,1 & 36,9 & 4,563 & 32,37 & 34,03 \\
\hline \multirow{2}{*}{$\begin{array}{l}\text { Cherkasy } \\
\text { w/i }\end{array}$} & $\begin{array}{c}10.07 . \\
2017\end{array}$ & 23 & 6,9 & 50 & 20,1 & 7,59 & 45 & 18,09 & 8,073 & 41,5 & 16,683 \\
\hline & $\begin{array}{l}16.08 . \\
2017\end{array}$ & 25 & 4,4 & 55 & 30,6 & 4,84 & 49,5 & 27,54 & 5,148 & 45,65 & 25,398 \\
\hline \multirow{2}{*}{$\begin{array}{l}\text { Svitlo- } \\
\text { vodsk } \\
\text { w/i }\end{array}$} & $\begin{array}{c}13.07 . \\
2017 \\
\end{array}$ & 23 & 7,2 & 50 & 29,1 & 7,92 & 45 & 26,19 & 8,424 & 41,5 & 24,153 \\
\hline & $\begin{array}{c}16.08 . \\
2017\end{array}$ & 25 & 5,8 & 54 & 34 & 6,38 & 48,6 & 30,6 & 6,786 & 44,82 & 28,22 \\
\hline \multirow{2}{*}{$\begin{array}{c}\text { Kremen- } \\
\text { chuk } \\
\text { w/i }\end{array}$} & $\begin{array}{c}04.07 . \\
2017\end{array}$ & 22 & 6,56 & 40 & 39,5 & 7,216 & 36 & 35,55 & 7,6752 & 33,2 & 32,785 \\
\hline & $\begin{array}{l}14.08 . \\
2017\end{array}$ & 25,3 & 6,7 & 59 & 36 & 7,37 & 53,1 & 32,4 & 7,839 & 48,97 & 29,88 \\
\hline
\end{tabular}

Table 2

Expenses on the installation construction

\begin{tabular}{|c|c|c|c|}
\hline № & Nomination & Model & Cost, UAH \\
\hline 1 & \multirow{2}{*}{ Filter } & SmartPondFilter EBF-1200G $\left(900 \mathrm{~m}^{3}\right)$ & 801,590 \\
\cline { 3 - 4 } 2 & Engine & SmartPondFilter EBF-1200G $\left(900 \mathrm{~m}^{3}\right)$ & 801,590 \\
\hline 3 & Hull & Keнтавp 4L22BT $(35 \mathrm{HP})$ & 51,424 \\
\hline 4 & (average cost of the sized hull) & 520,000 \\
\hline 5 & Construction of the installation & $20 \%$ from total cost of the components & $330,920.8$ \\
\hline 6 & Total & & $2,505,524.8$ \\
\hline
\end{tabular}


Table 3

Comparison of different types of filters

\begin{tabular}{|c|c|c|c|}
\hline Model & Smartpond Filter EBF 1200G & Smartpondfilter EBF-500G & Pondtech Filter 130i \\
\hline Volume 1/h & 100,000 & 30,000 & 25,000 \\
\hline $\begin{array}{c}\text { Dimensions, } \\
(\text { L x W x H) mm }\end{array}$ & $1350 \times 1400 \times 890$ & $1350 \times 720 \times 890$ & $1150 \times 760 \times 740$ \\
\hline UV lamp & + & + & + \\
\hline Built-in pump & + & + & + \\
\hline Price, $U A H$ & 801,590 & 559,300 & 66,419 \\
\hline
\end{tabular}

per hour), its physical parameters (length, width, and height), the presence of an ultraviolet lamp, whether the pump is built-in or not, and the price of the filter). The comparison was held out between 3 models of filters that were the most suitable for using in the installation. Namely there were: Smartpond Filter EBF 1200G, Smartpondfilter EBF-500G, and Pondtech Filter 130i. The comparison of the different filters is shown at the Table 3.

Table 3 explains the use of Smartpond Filter EBF $1200 \mathrm{G}$ instead of others. Although this filter has the biggest dimensional proportions and way higher price, its benefits overlap deficiencies. The amount of water that this filter can filtrate per one hour is more than two times bigger than capacity of others. Also, the dimensions of this filter in comparison to its abilities are reasonable, because such operational characteristics require corresponding space. At the same time Smartpondfilter EBF-500G and Pondtech Filter $130 \mathrm{i}$ cannot compete with the chosen model.

Conclusions. The expert valuation method showed two scenarios for installation implementation - pessimistic and optimistic. In case of pessimistic outcome the effectiveness will be $10 \%$. In case of optimistic scenario it will gain $17 \%$ effectiveness.
Hydro-chemical analysis of the surface waters state showed that factors that influence hydro-chemical water state are: anomalous temperature conditions; lack of snow and heavy precipitations; lack of floods.

Excessive and uncontrolled growth of algae or other aquatic plants may provide very high concentration of dissolved oxygen, it is so-called supersaturation.

The ability of the reservoir to self-cleaning is a lot lower than it should be.

For that reason there is a need to help nature with restoration of good water quality. There are quite a few different methods of water treatment, but not all of them are suitable to be applied in natural water reservoir.

The usage of an installation for reservoir cleaning will improve the ability of the reservoir to self-cleaning. If the installation is implemented before the period of algal bloom starts, significant changes in water quality can be achieved even after one year of operation, which will be enlarged with every year after.

The extracted algae can be further used for biogas production, for cosmetology and health care, in food industry, and as a source of nutrients in agriculture, not to mention benefit of algae removal from water for fish and other aquatic organisms.

\section{References:}

1. Takehiro Nakamura. Ecosystem-based river basin management: its approach and policy-level application. Special Issue: Japan Society of Hydrology and Water Resources. 2005. Vol. 17, Issue14. P. 271-272.

2. Barinova S. Essential and practical Bioindication Methods and Systems for the Water Quality. Assessment. International Journal of Environmental Science and Natural Resources. 2017. 2(3). P. 1-11.

3. Development of a procedure for determinating the basic parameter of aquatic ecosystems functioning environmental capacity / V. Isayenko, S. Madzhd, Y. Pysanko et. al.]. Eastern-European Journal of Enterprise Technologies. 2019. № 97. P. 21-28.

\section{Ткачук К.К., Тверда О.Я., Репін М.В. ЕФЕКТИВНІСТЬ ВПРОВАДЖЕННЯ УСТАНОВКИ ДЛЯ ОЧИЩЕННЯ ПРИРОДНОГО РЕЗЕРВУАРА}

Стаття присвячена основним проблемам небезпечної ситуачії на водоймах та річках від: скидів очищених промислових стічних вод, побутових стічних вод, збільщення кількості органічних речовин, зниження рівня води водойм у теплу пору року, активне неконтрольоване зростання синьо-зелених водоростей.

Для того щоб визначити заходи щодо покращення якості води у водоймах, у роботі запропоновано метод «вибору найкращої альтернативи». Цей метод дозволяє виконати порівняльний аналіз 
альтернативних заходів з використанням перерахунку, який включає технологічні параметри та організаційні заходи, забезпечені нормами. Запропоновано обтрунтування комплексного методу заходів щзодо покращення якості води. Рімення багатокритеріальної задачі методом вибору найкращих альтернатив без повної інформації дозволяє чисельно оцінити можливість зниження якості води та вибрати найкращий доступний метод підвищення якості води у водоймах. Для вибору та обтрунтування заходів, які забезпечать підвищення якості води у природних водоймах, було проведено порівняльний аналіз для визначення життєздатності альтернативних пропозицій, використовуючи перелік параметрів та заходи для пошуку найкращих альтернатив. Економічна ефективність модельованих заходів розраховується з показником загальної економічної ефективності витрат на охорону навколишнього середовища. Ефективність витрат визначається з огляду на етапи обтрунтування охорони навколишнього природнього середовища та в процесі оцінки результатів виконання завдань програми охорони навколишнього природного середовища та регіонального використання природних ресурсів на певній території. Визначення екологічного впливу природоохоронних заходів трунтується на порівнянні витрат на їх реалізацію з результатом, досягнутим завдяки ичим заходам.

Ключові слова: стічні води, якість води, комплекс заходів, аналіз життєздатності, природні ресурси. 